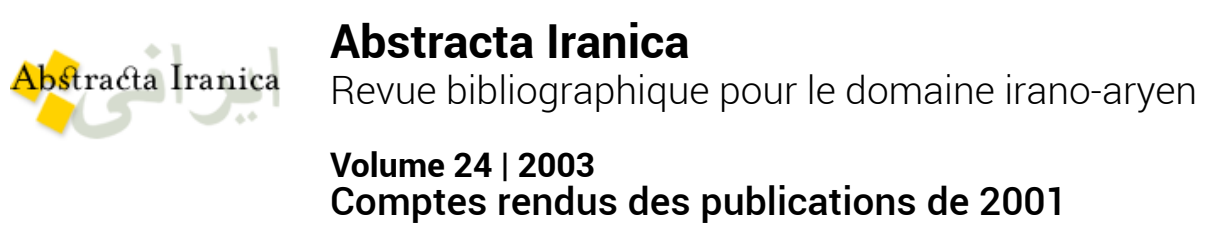

\title{
AVERTISSEMENT - Abstracta Iranica 24 - 2001
}

\section{Rédaction}

\section{OpenEdition}

Journals

Édition électronique

URL : http://journals.openedition.org/abstractairanica/35035

ISSN : 1961-960X

Éditeur :

CNRS (UMR 7528 Mondes iraniens et indiens), Éditions de l'IFRI

Édition imprimée

Date de publication : 15 mai 2003

ISSN : 0240-8910

Référence électronique

Rédaction, «AVERTISSEMENT - Abstracta Iranica 24 - 2001 », Abstracta Iranica [En ligne], Volume 24 | 2003, mis en ligne le 05 janvier 2010, consulté le 25 septembre 2020. URL : http:// journals.openedition.org/abstractairanica/35035

Ce document a été généré automatiquement le 25 septembre 2020.

Tous droits réservés 


\section{AVERTISSEMENT - Abstracta Iranica 24 - 2001}

\section{Rédaction}

1 Ce numéro 24 d'Abstracta Iranica, sorti avec plusieurs mois de retard, reflète les publications de l'année 2001, avec des rappels sur 2000, 1999 et exceptionnellement 1998 pour des ouvrages importants qui n'ont pas été recensés précédemment.

2 Ce retard de parution, dont nous nous excusons auprès de nos lecteurs, a permis de compléter le numéro préparé sous la direction de Christophe Balaÿ, qui a achevé son mandat de directeur de l'IFRI en décembre 2002.

3 Parallèlement, la structure des prochains numéros a été mise en place : dorénavant, la revue sera dotée d'un comité de rédaction, d'un comité de direction et d'un directeur qui ne sera plus nécessairement le directeur de l'IFRI, mais une personnalité scientifique choisie parmi les collaborateurs de la revue.

\section{INDEX}

Thèmes : Avant propos 